\title{
Skrining Fitokimia dan Uji Bioaktivitas Antibakteri dari Gorgonia Mopsella sp. *cf, Siphonogorgia sp. dan Villogorgia sp. terhadap Bakteri Pseudomonas aeruginosa dan Bacillus cereus \\ (Phytochemical screening test the antibacterial bioactivity of gorgonia Mopsella sp. "cf, Siphonogorgia sp. and Villogorgia sp. Againts Pseudomonas aeruginosa and Bacillus cereus)
}

\author{
Ni Made Marlin Suarjo Putri ${ }^{\left.1^{*}\right)}$, Febby Ester Fany Kandou ${ }^{1)}$, Marina Singkoh ${ }^{1)}$ \\ 1) Jurusan Biologi, Fakultas Matematika dan IImu Pengetahuan, \\ Universitas Sam Ratulangi Manado \\ ${ }^{\star}$ E-mail: Nimadems.putri@yahoo.com
}

Diterima 7 Juli 2019, diterima untuk dipublikasi 10 Agustus 2019

\begin{abstract}
ABSTRAK
Penelitian ini bertujuan untuk menguji bioaktivitas antibakteri dari ekstrak etanol Mopsella sp. * $c f$, Siphonogorgia sp. dan Villogorgia sp. terhadap Pseudomonas aeruginosa dan Bacillus cereus dan mengetahui golongan senyawa yang terkandung di dalamnya. Tahapan penelitian meliputi pengambilan dan penyiapan sampel, identifikasi Gorgonia, ekstraksi, skrining fitokimia, pembuatan larutan Mc. Farland, pembuatan media dan pengujian antibakteri. Ekstraksi dilakukan dengan cara maserasi menggunakan pelarut etanol. Pengujian bioaktivitas antibakteri menggunakan metode Kirby- Bauer. Hasil uji bioaktivitas antibakteri menunjukkan ekstrak etanol Mopsella sp. memiliki aktivitas antibakteri dengan kategori kuat $(13,5 \mathrm{~mm} \pm 2,60)$, Siphonogorgia sp. termasuk dalam kategori sedang (9 $\mathrm{mm} \pm 1,80)$, Villogorgia sp. tidak memiliki daya hambat $(6,5$ $\mathrm{mm} \pm 0,87)$ pada bakteri Pseudomonas aeruginosa. Sedangkan pada bakteri uji Bacillus cereus, pada sampel Mopsella sp tidak memiliki daya hambat, sampel Siphonogorgia sp. termasuk dalam kategori sedang $(8,3 \mathrm{~mm} \pm 0,58)$, Villogorgia sp. tidak memiliki daya hambat $(6,5 \mathrm{~mm} \pm 0,50)$. Golongan senyawa yang terkandung dalam Mopsella sp. yaitu flavonoid, saponin, tanin. Golongan senyawa pada Siphonogorgia sp. yaitu alkaloid (Wagner) menunjukkan positif sedangkan golongan senyawa pada Villogorgia sp. yaitu alkaloid dan flavonoid.

Kata kunci: skrining fitokimia, antibakteri, Mopsella sp., Siphonogorgia sp., Villogorgia sp.
\end{abstract}

\begin{abstract}
This study aims to examine the antibacterial bioactivity of ethanol extract of Mopsella sp. * cf, Siphonogorgia sp. and Villogorgia sp. against Pseudomonas aeruginosa and Bacillus cereus and find out the class of compounds contained therein. The stages of the research included sampling and preparation, Gorgonia identification, extraction, phytochemical screening, making Mc solution. Farland, making media and antibacterial testing. Extraction was carried out by maceration using ethanol solvent. Antibacterial bioactivity testing using the Kirby-Bauer method. Antibacterial bioactivity test results showed that ethanol extract of Mopsella sp. had antibacterial activity with a strong category $(13.5 \mathrm{~mm} \pm 2.60)$, Siphonogorgia sp. included in the medium category (9 $\mathrm{mm} \pm 1.80$ ), Villogorgia sp. had no inhibitory power $(6.5 \mathrm{~mm} \pm 0,87)$ in the Pseudomonas aeruginosa bacteria. Whereas in Bacillus cereus test bacteria, in Mopsella sp. sample did not have inhibitory power, Siphonogorgia sp. sample was included in the medium category ( $8.3 \mathrm{~mm} \pm 0.58$ ), Villogorgia sp. did not have inhibitory power $(6.5 \mathrm{~mm} \pm$ $0,50)$. The groups of compounds contained in Mopsella sp. are flavonoids, saponins, tannins. The group of compounds in Siphonogorgia sp., namely alkaloids (Wagner) showed positivity while the compound groups in Villogorgia sp. were alkaloids and flavonoids.

Key words: Phytochemical screening, Antibacterial, Mopsella sp., Siphonogorgia sp., Villogorgia sp.
\end{abstract}




\section{PENDAHULUAN}

Gorgonia merupakan koral yang mempunyai septa dan tentakel yang berjumlah delapan (Oktocoralia), umumnya berbentuk seperti pohon dengan banyak cabang pendukung dan termasuk dalam kelas Anthozoa (Antonius 2000). Teffu et al. (2015) menyatakan bahwa Gorgonia dikenal sebagai organisme yang menghasilkan senyawa terpenoid, alkaloid, flavonoid, fenol hidrokuinon, steroid, dan saponin. Senyawa ini sering digunakan dalam industri farmasi terutama dalam pembuatan obat-obat antibiotika, anti jamur dan anti tumor, serta antibakteri.

Menurut Lisa (2008), bakteri Pseudomonas aeruginosa adalah bakteri Gram negatif berbentuk batang, bergerak dengan flagella, dan bersifat aerob. Pseudomonas aeruginosa menyebabkan infeksi pada luka dan luka bakar, menghasilkan nanah berwarna hijau, dan biru (Hidayatullah 2014). Sedangkan bakteri Bacillus cereus merupakan bakteri Gram positif, bersifat aerob fakultatif, dan motil (Atlas dan Richard 1987). Bakteri ini dapat menyebabkan keracunan makanan (Todar 2008).

Beberapa penelitian yang telah dipublikasikan memberikan informasi bahwa gorgonia dapat menghasilkan senyawa metabolit sekunder sebagai antibakteri (Fuganti dan Serra 2000; Kelman et al. 2006). Penelitian ini bertujuan untuk menganalisis golongan senyawa kimia yang terkandung dalam ekstrak etanol gorgonia dan menguji bioaktivitas antibakteri dari ekstrak Gorgonia terhadap Pseudomonas aeruginosa dan Bacillus cereus.

\section{METODE}

\section{Pengambilan Sampel Gorgonia}

Pengambilan sampel dilakukan di lokasi perairan Pulau Bunaken, Manado, Sulawesi Utara dengan cara menyelam pada kedalaman 25-30 meter. Sampel dikumpulkan dan dibersihkan kemudian dimasukkan ke zip-lock dan coolbox untuk dibawa ke laboratorium. Identifikasi sampel dilakukan in situ dengan melihat morfologi dan disesuaikan dengan buku identifikasi dari Fabricus dan Alderslade (2001), Tuti (2018) kemudian dilihat dari beberapa website di internet.

\section{Ekstraksi}

Sampel gorgonia dipotong kecilkecil, dihaluskan kemudian dimasukkan ke dalam toples dan direndam dengan larutan etanol 96\% sampai sampel terendam semuanya, selanjutnya dibiarkan selama $3 \times 24$ jam. Sampel yang sudah direndam menghasilkan filtrat satu. Sampel gorgonia dipindahkan ke toples yang sudah diberi label kemudian ditambah dengan larutan etanol 96\% sampai terendam semuanya biarkan $3 \times 24$ jam, sampel tersebut menghasilkan filtrat 2. Sampel dipindahkan lagi ke toples yang sudah diberi label kemudian ditambah dengan larutan etanol $96 \%$ sampai terendam semuanya dan dibiarkan selama $3 \mathrm{x}$ 24 jam, sampel tersebut menghasilkan filtrat 3 . Filtrat 1,2 , dan 3 kemudian disaring dan dijadikan satu, lalu dievaporasi hingga kering dan ditimbang menggunakan timbangan analitik dan didapatkan ekstrak kasar etanol untuk pengujian selanjutnya.

\section{Skrining fitokimia \\ Pemeriksaan alkaloid}

Pengujian senyawa alkaloid pada sampel gorgonia dilakukan dengan menggunakan metode Mayer, Wagner dan Dragendorff. Hasil uji alkaloid dengan metode Mayer yang positif mengandung alkaloid yaitu yang mengandung endapan berwarna putih di dasar tabung, kemudian metode Wagner yang positif mengandung alkaloid yaitu yang mengandung endapan yang berwarna coklat hingga warna kuning, kemudian 
untuk metode Dragendorff yang positif mengandung alkaloid yaitu mengandung endapan berwarna merah bata (coklat hingga berwarna jingga) (Harbone dalam Djoronga et al. 2014).

\section{Pemeriksaan flavonoid}

Ekstrak dimasukkan ke dalam tabung reaksi, ditambahkan $5 \mathrm{~mL}$ etanol dan dipanaskan selama 5 menit dalam tabung reaksi. Selanjutnya ditambahkan 10 tetes $\mathrm{HCl}$ pekat, kemudian ditambahkan 0,2 gram serbuk Mg. Adanya flavonoid ditunjukkan oleh timbulnya warna merah coklat, kuning, dan jingga (Harbone 1987).

\section{Pemeriksaan steroid/triterpenoid}

Ekstrak ditambahkan $\mathrm{CH}_{3} \mathrm{COOH}$ glasial sebanyak 10 tetes dan $\mathrm{H}_{2} \mathrm{SO}_{4}$ pekat sebanyak 2 tetes. Larutan dikocok perlahan dan biarkan selama beberapa menit. Jika larutan triterpenoid menjadi positif maka larutan akan berubah menjadi warna merah atau ungu. Apabila larutan steroid positif maka larutan akan berubah menjadi warna biru atau hijau (Nohong 2009).

\section{Pemeriksaan saponin}

Ekstrak ditambahkan dengan 10 $\mathrm{mL}$ akuades kemudian dikocok kuat. Selanjutnya ekstrak didiamkan dan diamati apabila terlihat busa. Terdapatnya saponin pada sampel akan ditandai dengan terbentuknya busa yang stabil selama kurang lebih 15 menit (Darwis 2000).

\section{Pemeriksaan tanin}

Ekstrak ditambahkan dengan 50 $\mathrm{mL}$ akuades, didihkan selama 15 menit lalu didinginkan.Filtrat sejumlah $5 \mathrm{~mL}$ dipindahkan pada tabung reaksi, diteteskan pereaksi $\mathrm{FeCl}_{3}$, bila terjadi warna hitam kehijauan menunjukkan adanya golongan senyawa tanin (Pandiangan 2009).

\section{Pembuatan Standar Kekeruhan (Larutan Mc. Farland)}

Larutan $\mathrm{H}_{2} \mathrm{SO}_{4} \quad 0,36 \mathrm{~N}$ sebanyak 9,5 $\mathrm{mL}$ dicampurkan dengan larutan $\mathrm{BaCl}_{2} \cdot{ }_{2} \mathrm{H}_{2} \mathrm{O} 1,175 \%$ sebanyak $0,5 \mathrm{~mL}$ dalam erlenmeyer. Kemudian dikocok sampai terbentuk larutan yang keruh. Kekeruhan ini dipakai sebagai standar kekeruhan suspensi bakteri uji (Borges dan Bresson 2004).

\section{Pembuatan Larutan Kontrol Positif}

Satu kapsul berisikan serbuk kloramfenikol sebanyak $25 \mathrm{mg}$. Serbuk di masukkan ke dalam wadah botol kaca dengan akuades sebanyak $5 \mathrm{~mL}$ untuk memperoleh larutan stok kloramfenikol dengan konsentrasi 250 $\mu \mathrm{g} / 50 \mu \mathrm{L}$.

\section{Pembuatan Media Agar Miring}

Untuk pembuatan inokulan bakteri, sebanyak $5 \mathrm{~mL}$ media nutrient agar dimasukkan ke dalam tabung reaksi, kemudian dibiarkan dingin dan mengeras pada kemiringan $30^{\circ}$. Bakteri di inokulasi menggunakan jarum ose dan di inkubasi pada suhu $37^{\circ} \mathrm{C}$ selama $1 \times 24$ jam.

\section{Pembuatan Media Agar Pengujian Antibakteri}

Nutrient agar (NA) ditimbang sebanyak 16,8 g dilarutkan $600 \mathrm{~mL}$ akuades kemudian dipanaskan di atas hot plate sampai mendidih dan diperoleh larutan jernih. Selanjutnya disterilkan di dalam autoklaf pada suhu $121^{\circ} \mathrm{C}$ selama 15 menit.

\section{Pembuatan Suspensi Bakteri Uji.}

Disuspensikan bakteri uji dengan larutan $\mathrm{NaCl} 0,9 \%$ sebanyak $3 \mathrm{~mL}$, kemudian suspensi bakteri ini dibuat disetarakan kekeruhannya dengan larutan Mc. Farland.

\section{Pengujian Aktivitas Antibakteri}

Pengujian aktivitas ekstrak gorgonia dilakukan dengan prosedur sebagai berikut: ekstrak dari masingmasing sampel ditimbang sebanyak 0,5 gram dan dilarutkan dengan 
akuades $0,5 \mathrm{~mL}$ (1:1), kemudian dimasukkan kertas cakram selama 15 menit ke dalam masing-masing sampel. Selanjutnya media nutrient agar (NA) dituangkan ke dalam cawan petri kemudian diambil suspensi bakteri uji 0,5 $\mu \mathrm{L}$ dimasukkan ke dalam cawan petri tersebut, dihomogenkan dan didiamkan hingga media memadat. Setelah media padat diletakkan 6 kertas cakram berukuran $6 \mathrm{~mm}$ dan diatur sehingga terdapat daerah yang cukup. Kemudian diinkubasi dalam inkubator pada suhu $37^{\circ} \mathrm{C}$ selama $1 \times 24$ jam.

\section{HASIL DAN PEMBAHASAN}

Hasil identifikasi morfologi dari sampel Mopsella sp. (Gambar 1). Mopsella sp termasuk dalam kelas Anthozoa, ordo: Alcyonacea, famili: Melithaeidae, dan genus: Mopsella * $\mathrm{cf}$ (Guido 2019)
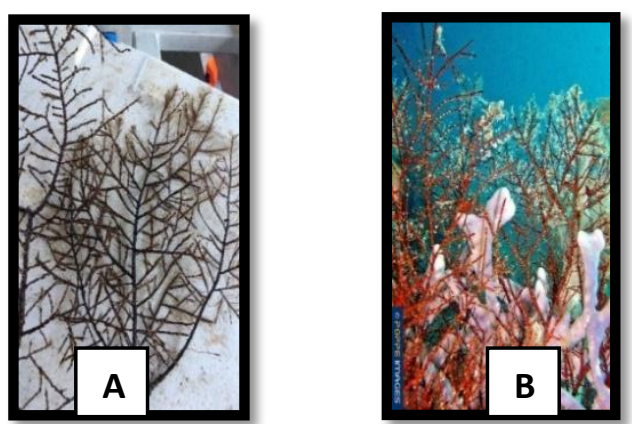

Gambar 1. Morfologi Mopsella sp.(A. Hasil Identifikasi, B. Mopsella Sumber Guido, 2019)


Gambar 2. Morfologi Siphonogorgia sp. (A. Hasil Identifikasi, B. Siphonogorgia $\mathrm{sp}$ ) Sumber: Water (2019)
Hasil identifikasi dari sampel Siphonogorgia sp. (Gambar 2). Siphonogorgia sp tergolong dalam ordo: Alcyonacea, famili: Nidaliidae, dan genus: Siphonogorgia (Flanders 2019). Hasil identifikasi dari sampel Villogorgia sp. (Gambar 3). Villogorgia sp termasuk dalam Kelas: Anthozoa, Ordo: Alcyonaceae, Famili: Plexauridae, dan genus: Villogorgia (Flanders 2019).
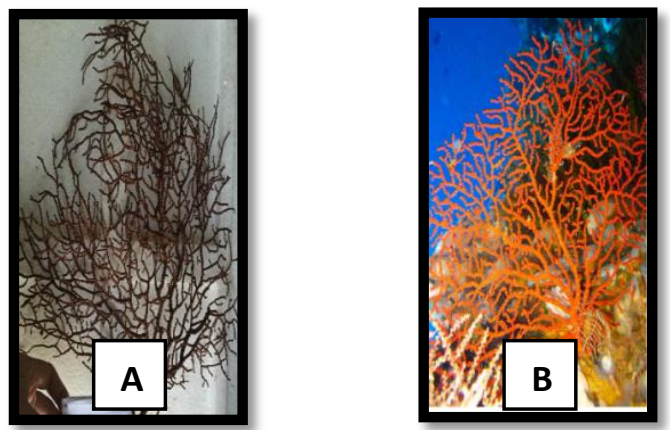

Gambar 3. Morfologi Kipas Laut Villogorgia sp. (Hasil Identifikasi, B. Villogorgia sp) Sumber Tuti ( 2018).

Hasil identifikasi kandungan kimia ekstrak etanol dapat dilihat pada Tabel 1. Uji bioaktivitas antibakteri ekstrak etanol pada sampel Mopsella sp., Siphonogorgia sp., Villogorgia sp. terhadap bakteri Pseudomonas aeruginosa dan Bacillus cereus menggunakan metode difusi agar Kirby Bauer. Metode ini dipilih karena cepat, mudah dan sederhana dalam pengerjaannya. Prinsip dari metode difusi ini ialah terbentuknya diameter zona hambat di sekitar kertas cakram yang telah diresapi larutan uji setelah media agar yang ditanami bakteri diinkubasi selama $1 \times 24$ jam pada suhu $37^{\circ} \mathrm{C}$ (Davis dan Stout 2009). 
Tabel 1. Hasil Skrining Fitokimia beberapa jenis Kipas Laut.

\begin{tabular}{lccc}
\hline Uji Fitokimia & & Nama Sampel & \\
& Mopsella sp & Siphonogorgia sp & Villogorgia sp. \\
\hline Alkoloid $\quad$ Meyer & + & - & + \\
.$\quad$ Dragendorf & - & - & + \\
. Wagner & - & + & - \\
Flavonoid & + & - & + \\
Streroid/ & - & - & - \\
Triterpenoid & - & - & - \\
Saponin & + & - & - \\
Tanin & + & & \\
\hline
\end{tabular}

Tabel 2. Hasil pengukuran diameter zona hambat dan standar deviasi pada Bakteri Pseudomonas aeruginosa dan Bacillus cereus.

\begin{tabular}{|c|c|c|c|c|c|}
\hline \multirow[b]{2}{*}{ Bakteri } & \multicolumn{5}{|c|}{ Diameter Zona Hambat (mm) } \\
\hline & Mopsella sp. & Siphonogorgia sp. & $\begin{array}{c}\text { Villogorgia } \\
\text { sp. }\end{array}$ & Kontrol (+) & Kontrol (-) \\
\hline P.a & $13,5 \pm 2,60$ & $9 \pm 1,80$ & $6,5 \pm 0,87$ & $20 \pm 2,50$ & $0,00 \pm 0,00$ \\
\hline B.c & $6 \pm 0,00$ & $8,3 \pm 0,58$ & $6,5 \pm 0,50$ & $19,1 \pm 1,04$ & $0,00 \pm 0,00$ \\
\hline
\end{tabular}

Zona halo adalah zona yang hanya menghambat pertumbuhan bakteri tetapi tidak dapat membunuh karena bersifat bakteriostatis, sedangkan zona bening menunjukkan ekstrak bersifat bakteriosidal artinya mampu membunuh bakteri. Hal ini sesuai dengan pernyataan Madigan (2000) menyatakan senyawa bakteriostatik bersifat menghambat pertumbuhan tetapi tidak membunuh, sedangkan senyawa bakteriosidal mampu membunuh bakteri. Pengujian pada bakteri Pseudomonas aeruginosa didapatkan hasil dari sampel Mopsella sp. sebesar (13,5 \pm 2,60), sedangkan pada bakteri Bacillus cereus didapatkan hasil sebesar $(0,00 \pm 0,00)$. Kemudian untuk pengujian aktivitas antibakteri pada bakteri Pseudomonas aeruginosa termasuk dalam kategori kuat dan terlihat adanya zona halo di sekitar kertas cakram dengan diameter yang cukup besar. Zona halo tersebut hanya bersifat bakteriostatis artinya ekstrak Mopsella sp. hanya mampu menghambat pertumbuhan bakteri. Menurut Madigan dalam Alamsyah (2014), hal ini karena ekstrak hanya dapat menghambat pertumbuhan bakteri dengan cara menghambat sintesis protein dengan pengikatan ribosom suatu organisme. Ikatan tersebut tidak begitu kuat sehingga ketika konsentrasi dan stabilitas menurun maka antimikroba akan melepas ribosom yang mengakibatkan bakteri dapat tumbuh kembali. Kemudian hasil dari pengujian zona hambat pada bakteri Bacillus cereus yaitu tidak adanya zona hambat yang dihasilkan dari sampel Mopsella sp. Menurut Rahmadani (2015), hal ini dikarenakan bakteri Gram positif terdiri dari beberapa lapisan peptidoglikan yang membentuk struktur yang tebal dan kaku serta mengandung substansi dinding sel yang disebut teikoat.

Selanjutnya

Siphonogorgia sp pada sampel Pseudomonas aeruginosa 
menunjukkan hasil sebesar $(9 \pm 1,80)$ sedangkan pada bakteri Bacillus cereus sebesar $(8,3 \pm 0,58)$, dari hasil diameter zona hambat kedua bakteri terlihat bahwa adanya zona bening. Zona bening menunjukkan bahwa ekstrak bersifat bakteriosida yang artinya memiliki kemampuan membunuh bakteri. Dapat dilihat pada bakteri Pseudomonas aeruginosa dan bakteri Bacillus cereus zona bening yang terlihat termasuk dalam kategori sedang.

Pada bakteri Pseudomonas aeruginosa sampel Villogorgia $\mathrm{sp}$. menunjukkan hasil sebesar (6,5 \pm $0,87)$, sedangkan pada bakteri Bacillus cereus sebesar $(6,5 \pm 0,50)$. Ekstrak Villogorgia sp. belum mampu membunuh masing-masing bakteri uji. $\mathrm{Hal}$ ini ditunjukkan dengan daerah kertas cakram pada kedua bakteri memiliki diameter zona hambat yang kecil, kemungkinan konsentrasi etanol yang lebih tinggi diperlukan, sehingga mampu membunuh bakteri. Kemudian ada beberapa faktor yang bisa mempengaruhi ukuran daerah penghambatan yaitu sensitivitas organisme, medium kultur, kondisi inkubasi, dan kecepatan difusi agar (Schlegel dan Schmidt 1994).

Senyawa metabolit sekunder berfungsi untuk mempertahankan diri dari kondisi lingkungan yang kurang menguntungkan. Peranan atau fungsi alkaloid itu sendiri sebagai pelindung dan pengatur kerja hormon. Adapun senyawa metabolit sekunder yaitu alkaloid, steroid, triterpenoid, flavonoid, saponin dan tanin. Hampir semua alkaloid yang ditemukan di alam mempunyai keaktifan biologis tertentu, ada yang sangat beracun tetapi adapula yang sangat berguna dalam pengobatan (Kandou et al 2006). Untuk hasil pengujian skrining fitokimia Mopsella sp. dapat dilihat bahwa sampel mengandung senyawa aktif alkaloid pereaksi (Meyer), flavonoid, saponin, dan tanin. Sampel Mopsella sp. senyawa alkaloid mendapatkan hasil negatif, sampel dikatakan mengandung alkaloid jika reaksi positif yang membentuk endapan sekurang-kurangnya dua reaksi dari golongan reaksi pengendapan yang dilakukan (Setiawan 2013). Sampel Siphonogorgia sp. mengandung alkaloid (Wagner) (Tabel 1). Sampel Siphonogorgia sp. hanya positif pada satu pereaksi yaitu pereaksi Wagner yang artinya sampel memiliki hasil negatif untuk senyawa alkaloid. Adapun senyawa aktif yang terkandung pada sampel Villogorgia sp. yaitu alkaloid (Meyer, Dragendrof) menunjukkan hasil positif alkaloid dan Flavonoid.

\section{KESIMPULAN}

Ekstrak Mopsella sp. pada bakteri Pseudomonas aeruginosa termasuk dalam kategori kuat, sedangkan pada bakteri Bacillus cereus tidak memiliki daya hambat. Ekstrak Siphonogorgia sp. pada bakteri Pseudomonas aeruginosa dan Bacillus cereus termasuk dalam kategori sedang. Ekstrak Villogorgia sp. pada bakteri Pseudomonas aeruginosa tidak memiliki daya hambat, sedangkan Bacillus cereus termasuk dalam kategori sedang. Hasil uji skirining fitokimia menunjukkan sampel Mopsella sp. mengandung senyawa flavonoid, saponin dan tanin. Sampel Siphonogorgia sp. mengandung senyawa alkaloid (Wagner) menunjukkan hasil positif. Sampel Villogorgia sp. mengandung senyawa alkaloid, flavonoid.

\section{DAFTAR PUSTAKA}

Atlas RM, Richard B (1987) Microbiallogy: Fundamentals and Applications (Second Edition). The Benjamin Cummings Publishing Company, California.

Antonius A (2000) Threats to and Protection of Coral Reefs. University of Vienna, Germany. Alamsyah K (2014) Aktivitas Antibakteri Ekstrak Rumput Laut 
Sargassum cinereum (J.G. Agardh) dari Perairan Pulau Panjang Jepara Terhadap Bakteri Escherichia coli dan Staphylococcus epidermidis. Journal Of Marine Research. 3(2): 69-78.

Borges M, Bresson W (2004) Delivery Methods for Introducing Endophitic Bacteria into Maize Biocontrol. 49: 315-322.

Davis W and Stout T (2009) Disc Plate Methods of Microbiological Antibiotic Assay. Microbiolgy. 22(4): 666-670.

Darwis D (2000) Uji Kandungan Fitokimia Metabolit Sekunder. Metode Lapangan dan Laboratorium. Workshop Pengembangan Sumber Daya Manusia dalam Bidang Kimia Organik Bahan Alam Hayati. Ditjen Dikti Depniknas, Padang.

Djoronga I, Pandiangan D, dan Kandou F (2014) Penapisan Alkaloid Pada Tumbuhan Paku dari Halmahera Utara. Mipa Unsrat Online. 3(2):102-107.

Kandou F, Pandiangan D, Nainggolan $N$ (2006) Inventarisasi dan Penapisan Alkaloid Tumbuhan Obat Tradisional Suku Sanger di Kabupaten Sangihe Sulawesi Utara.12(3):196-210.

Fabricus K dan Alderslade P (2001) Soft Corals and Sea Fans. Australian Institute of Marine Science and The Museum and Art Gallery of Northen Territory, Australia.

Fuganti C dan Serra S (2000) Baker's Yeast-mediated

Enantioselective synthesis of the Bisabolane Sesquiterpenes (+)-curcuphenol,

$(+)-$ xanthorrhizol, (-)-curcuquinone and (+)-curcuhydroquinone. Jurnal Chem. Soc Perkin Trans. 1: 3758.

Flanders Marine Institute (2019) Word Register of Marine Spesies: Villogorgia. http://www.marinespecies.org/a phia. php? $\mathrm{p}=$ taxdetails\&id $=1253$ 16. [15 Mei 2019].

Guido T (2019) Poppe \& Philippe Poppe - Conchology, Inc. https://www.poppeimages.com $/ ? \mathrm{t}=17$ \&photoid $=900$ 370. [30 April 2019].

Harbone $J$ (1987) Metode Fitokimia Penuntun Cara Modern Menganalisis Tumbuhan. ITB, Bandung.

Hidayatullah S (2014) Analisa Komponen Kimia Dan Uji Antibakteri Asap Cair Tempurung Kelapa Sawit (Elaeis guineensis Jacq.) pada Bakteri Staphylococcus aureus dan Psedumonas aeruginosa [Skripsi]. Fakultas Kedokteran Dan IImu Kesehatan UIN, JAKARTA.

Kelman $D$ and Kashman E, Rosenberg A, Kushmaro and Lova Y (2006) Antimicrobial Activity of Red Sea Corals. mar. Jurnal Biol. 149: 357-363.

Lisa N (2008) Uji Aktivitas In Vitro Levofloksasin Terhadap Isolat Staphylococcus aureus dan Pseudomonas aeruginosa Resisten Multiobat Di RSU Dr. Soetomo Surabaya: Isolat dari Pasien Infeksi Kulit dan Infeksi Saluran Kemih. Skripsi Tidak Diterbitkan Surabaya: Fakultas Kedokteran UNAIR Surabaya.

Madigan M, Martinko J, Parker J (2000) Brock Biology of Microorganisms, Ninth Edition, Prentice-Hall, London.

Nohong (2009) Skrining Fitokimia Tumbuhan Ophiopogon jaburan Lodd dari Kabupaten Kolaka Provinsi Sulawesi Tenggara. FMIPA, Universitas Haluoleo Kendari. Jurnal Pembelajaran Sains. 5 (2): 172-178.

Pandiangan D (2009) Produksi Metabolit Sekunder Alkaloid Secara In Vitro. UNPAD Press. Bandung. 12-15.

Rahmadani Fitri (2015) Uji Aktivitas Antibakteri dari Ekstrak Etanol 
Putri dkk., Skrining fitokimia... $\mid 90$

96\% Kulit Batang Kayu Jawa (Lannea coromandelica)

Terhadap Bakteri

Staphylococcus aureus dan Escherichia coli, Helicobacter pylori, Pseudomonas aeruginosa. [Skripsi]. Jakarta: Fakultas Kedokteran dan IImu Kesehatan UIN Syarif Hidayatullah.

Schlegel H and Schmidt K (1994) Microbiology Six Edition. (Terjemahan Mikrobiologi Umum edisi Keenam. Diterjemahkan Oleh Tedjo Baskoro). Gajah Mada University Press. Yogyakarta.

Teffu $H$, Suwandi $R$ dan Nurjanah (2015) Komponen Kimia dan
Bioaktif Akar Bahar Gorgonian (Genus Rumphella and Hicksonella) from Raijua IslandEast Nusa Tenggara. 18(1).

Tuti Yosephine (2018) Gorgonians in Indonesia Waters. Pusat Penelitian Oseanografi- LIPI, Jakarta.

Todar K (2008) Bacillus cereus Keracunan Makanan. www.textbookofbacteriology.net [26 oktober 2018].

Water Frame (2015) Shiponogorgia sp; https://www.alamy.com/redsoft-coral-siphonogorgia-spmarovo-lagoon-solomonislands-image279620990. html. [30 April 2019]. 